\title{
HADHANAH ANAK PASCA PUTUSAN \\ PERCERAIAN (STUDI KOMPARATIF HUKUM \\ ISLAM DAN HUKUM POSITIF INDONESIA)
}

\author{
Husnatul Mahmudah, Juhriati, Zuhrah \\ Institut Agama Islam Muhammadiyah Bima \\ Sekolah Tinggi Ilmu Hukum Muhammadiyah Bima \\ Jl. Anggrek No. 16 Ranggo Na'e Kota Bima \\ arraynez@gmail.com; juhriatiburhan@gmail.com; \\ zhoemachy@gmail.com
}

\section{Abstract:}

Penelitian ini merupakan studi komparasi terkait hadhanah anak pasca putusan perceraian dalam perspektif hukum Islam dan hukum positif Indonesia. Penelitian ini bertujuan untuk menganalisis bagaimanakah dasar hukum pelaksanaan hadhanah pada anak pasca perceraian dalam dua perspektif hukum tersebut. Jenis penelitian ini merupakan penelitian kualitatif dengan menggunakan pendekatan penelitian hukum yuridis normatif. Hadhanah merupakan hak anak yang harus dipenuhi oleh kedua orang tua. Hadhanah meliputi pendidikan dan pengasuhan dari orang dewasa selaku orang tua kepada anak yang belum dewasa. Hasil penelitian ini menyimpulkan bahwa hadhanah dalam hukum Islam sangat mengedepankan kepentingan terbaik bagi anak. Hal ini tertuang dalam sumber utama hukum Islam (al-Qur'an dan Hadis) bahwa anak-anak pun memiliki hak yang melekat dalam hubungannya dengan kedua orang tuanya, meskipun telah terjadi perceraian. Begitu juga dalam hukum positif di Indonesia. Kekuasaan orang tua terhadap anak pasca 
perceraian menurut ketentuan kedua hukum (Hukum Islam dan Hukum Positif Indonesia) tersebut adalah sejalan, makna kekuasaan orang tua terhadap anak sangat berkolerasi terhadap makna perkawinan dan perceraian sebagaimana diatur oleh KHI dan UU Perkawinan. Pemaknaan hadhanah yang terdapat di dalam kedua hukum ini ternyata juga sejalan dengan pemaknaan perlindungan anak sebagaimana diatur di dalam UU Perlindungan anak, yaitu memberikan yang terbaik kepada anak. Sehingga kedua orang tua yang bercerai harus tetap memenuhi hadhanah anaknya sesuai dengan hak anak dalam UU Perlindungan Anak yaitu, hak hidup, tumbuh kembang, perlindungan dan partisipasi.

Keywords: Hadhanah, Perceraian, Hukum Islam, Hukum Positif.

\section{Pendahuluan}

Perceraian merupakan sebuah tindakan hukum yang dibenarkan oleh agama dalam keadaan darurat yang dapat dilalui oleh suami istri bila ikatan perkawinan (rumah tangga) tidak dapat dipertahankan keutuhan dan kelanjutannya. Sifat darurat dimaksud, berarti sudah ditempuh berbagai cara dan teknik untuk mencari kedamaian diantara kedua belah pihak, baik melalui hakam (mediator) dari kedua belah pihak maupun langkah-langkah dan teknik yang diajarkan oleh al-Quran dan hadis. ${ }^{1}$

Pasal 113 Kompilasi Hukum Islam menyebutkan bahwa perkawinan dapat putus karena tiga hal, yakni kematian, perceraian dan putusan pengadilan. Berdasarkan pasal 39 Undang-undang Nomor 1 Tahun 1974, perceraian hanya dapat

1 Zainuddin Ali, Hukum Perdata Islam di Indonesia (Jakarta: Sinar Grafika Indonesia, 2006), hal.73.

Sangaji Jurnal Pemikiran Syariah dan Hukum 
dilakukan di depan pengadilan setelah pengadilan yang bersangkutan berusaha dan tidak berhasil mendamaikan kedua belah pihak. Untuk melakukan perceraian juga harus dengan cukup alasan bahwa sudah tidak terdapat lagi kecocokan dan persamaan tujuan dalam membina rumah tangga, artinya sudah tidak dapat hidup rukun kembali sebagai sepasang suami istri.

Suatu gugatan perceraian bisa mengundang berbagai macam permasalahan. Di samping gugatan cerai itu sendiri, muncul pula masalah lain sebagai akibat dikabulkannya gugatan cerai tersebut, seperti masalah pembagian harta bersama dan bilamana mempunyai keturunan maka timbul pula permasalahan tentang siapa yang lebih berhak melakukan Hadhanah (pemeliharaan terhadap anak). ${ }^{2}$ Anak yang lahir dari perkawinan itu, tentu memiliki sejumlah hak dan kewajiban dari dan kepada orang tuanya, terutama menyangkut hak anak untuk mendapatkan makan dan minum serta pakaian dan tempat tinggal di samping hak-hak pemeliharaan dan pendidikan. ${ }^{3}$

Berdasarkan uraian permasalahan tersebut diatas, menarik kiranya untuk mengkaji secara mendalam dalam bentuk penelitian yang berjudul "Hadhanah terhadap Anak Pasca Putusan Perceraian (Studi Komparatif Hukum Islam dan Hukum Positif Indonesia)."

2 Satria Efendi M. Zein, Problematika Hukum Keluarga Islam Kontemporer (Analisis Yurisprudensi dengan Pendekatan Ushuliyya) (Jakarta: Prenada Media, 2004), hal.189.

${ }_{3}$ Muhammad Amin Suma, Hukum Keluarga Islam di Dunia Islam, ed.revisi II (Jakarta: Raja Grafindo Persada, 2005), hal.26. 


\section{Metode Penelitian}

Jenis penelitian ini adalah penelitian kualitatif dengan menggunakan pendekatan penelitian hukum yuridis normatif, ${ }^{4}$ dimana penggalian sumber hukumnya dilakukan dengan sumber data sekunder yakni mengacu pada referensi kepustakaan seperti undang-undang, buku-buku yang relevan, jurnal maupun sumber dari data online. Pendekatan yang digunakan dalam penelitian ini adalah pendekatan Undang-Undang, ${ }^{5}$ dimana penulis melakukan pengkajian dan menganalisis peraturan perundang-undangan mengenai hak anak (hadhanah) yang diatur dalam regulasi hukum Islam maupun hukum positif Indonesia.

Sumber data yang digunakan dalam penelitian ini ada 3 (tiga): (1) Bahan Hukum Primer yaitu data berupa data kepustakaan yang diperoleh dari regulasi utama yang menjadi rujukan penulisan ini karena mengingat penulisan ini bersifat tinjauan yuridis normatif. Antara lain sumber data kepustakaan yang digunakan yaitu regulasi berupa undang-undang, ayat dan hadis, buku-buku yang relevan dengan judul. (2) Bahan hukum Sekunder yaitu data yang diperoleh dari internet baik itu berupa artikel, opini dan tulisan ilmiah lainnya untuk menunjang daripada data primer. (3) Bahan hukum Tersier yaitu bahan pelengkap berupa kamus hukum untuk menerjemahkan katakata hukum yang tidak dimengerti. Adapun teknik analisis data dalam penulisan ini menggunakan teknik analisis data secara kualitatif $^{6}$ yakni yang bersifat deduktif, dimana analisis ini

4 Soerjono Soekanto dan Sri Mamudji, Penelitian Hukum Normatif Suatu Tinjauan Singkat, Cetakan ke-11. (Jakarta: PT Raja Grafindo Persada, 2009), hal.13.

${ }^{5}$ Peter Mahmud Marzuki, Penelitian Hukum (Jakarta: Kencana, 2009), hal.35

6 Salim HS \& Erlies Septiana Nurbani, 2013. Penerapan Teori Hukum Pada Penelitian Tesis dan Disertasi. Jakarta: PT raja Grafindo Persada. Hal. 17

Sangaji Jurnal Pemikiran Syariah dan Hukum 
menjelaskan masalah secara umum terlebih dahulu sehingga dapat ditarik kemasalah yang lebih khusus.

\section{Hasil Penelitian dan Pembahasan}

\section{Hak Anak (hadhanah) Pasca Perceraian Perspektif Hukum Islam}

Pemeliharaan anak juga disebut pengasuhan anak dalam Islam dinamakan hadhanah. Secara etimologi hadhanah berarti disamping atau berada di bawah ketiak. ${ }^{7}$ Hadhanah berasal dari kata hadhana-yahdhunu-hadhanatun yang berarti mengasuh atau memeluk anak. ${ }^{8}$ Kamal Muhtar memberi pengertian hadhanah, menurut bahasa, hadhanah berasal dari kata "al-hidlnu" yang berarti "rusuk". Kemudian perkataan hadhanah dipakai sebagai istilah dengan arti "pendidikan anak" karena seorang ibu yang mengasuh atau menggendong anaknya sering meletakkannya pada sebelah rusuknya. ${ }^{9}$

Secara etimologi kata hadhanah berarti "al-jamb" yang berarti di samping atau berada di bawah ketiak. ${ }^{10}$ Atau bisa juga diartikan meletakkan sesuatu dekat tulang rusuk seperti menggendong, atau meletakkan sesuatu pada pangkuan. ${ }^{11}$ Maksudnya adalah merawat, mendidik seseorang yang belum

7 Abdul Aziz Dahlan, Ensiklopedia Hukum Islam, (Jakarta: Ichtiar Baru Van Hoepe, 1999), hal. 415

${ }^{8}$ Mahmud Yunus, Kamus Bahasa Arab-Indonesia, (Jakarta: Hidakarya Agung, 2000), hal. 104

${ }^{9}$ Kamal Muhtar, Asas-asas Hukum Islam tentang Perkawinan (Jakarta: Bulan Bintang), hal.129

${ }^{10}$ Ibnu Manzhur, Lisan al-Araby (Mesir: Dar al-Maarif, tth) hal.911

11 Satria Efendi M. Zein, Problematika Hukum Keluarga Islam Kontemporer (Jakarta: kencana, 2004), hal. 166 
mumayyiz atau yang kehilangan kecerdasannya, karena mereka tida bisa mengerjakan keperluan sendiri. ${ }^{12}$

Dalam istilah fiqih digunakan dua kata namun ditujukan untuk maksud yang sama yaitu kaffalah atau hadanah. Adapun yang dimaksud dengan kaffalah atau hadanah dalam arti sederhana ialah "pengasuhan" dan "pemeliharaan". Dalam arti lebih lengkap adalah pemeliharaan anak yang masih kecil setelah terjadinya putus perkawinan. Hal ini dibicarakan dalam fikih karena secara praktis antara suami dan istri telah terjadi perpisahan sedangkan anak-anak memerlukan bantuan dari ayah dan/atau ibunya. ${ }^{13}$ Secara syariat, mengasuh anak diartikan sebagai menjaga orang yang belum mampu mandiri mengurus urusannya sendiri,mendidik dan menjaganya dari sesuatu yang merusak atau membahayakannya. ${ }^{14}$

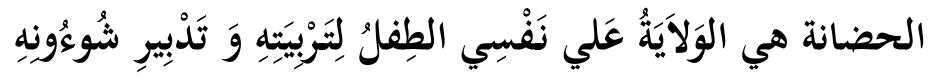

"Hadanah adalah asuhan terhadap seorang anak kecil untuk dididik dan diurus semua urusannya." 15

Dalam literatur fikih hadhanah didefinisikan dalam beberapa terminologi, diantaranya menurut Sayyid Syabiq hadhanah adalah suatu sikap pemeliharaan terhadap anak kecil yang belum dapat membedakan mana yang baik dan buruk dan belum mampu mengurus dirinya sendiri. Menjaga, mendidik dan mengasuhnya baik fisik, mental maupun akal

12 Amir Syarifuddin, Hukum Perkawinan di Indonesia, (Jakarta: Kencana, 2006), hal. 326

${ }^{13}$ Ibid., hal. 327-328

14 Ahmad Muhammad Yusuf, Ensiklopedi Tematis Ayat al-Qur'an dan Hadis Jilid 7, (Jakarta: Widya Cahaya, 2009), hal. 188

15 Muhammad Rawwas Qal'ahji, Penerjemah M.Abdul Mujeb, Ensiklopedi Figh Umar Bin Khathab, (Jakarta: Raja Grafindo Persada, 1999), hal. 103

Sangaji Jurnal Pemikiran Syariah dan Hukum 
agar mampu menjalankan kehidupan yang sempurna dan bertanggung jawab. ${ }^{16}$

Pandangan lain yang serupa dalam istilah fikih tentang hadhanah adalah tugas menjaga, mengasuh atau mendidik bayi/anak kecil sampai mampu menjaga atau dapat mengatur dirinya sendiri. Anak yang sah nasabnya berarti tugas hadhanah akan dipikul oleh kedua orang tuanya sekaligus. ${ }^{17}$ Selanjutnya ditegaskan pula oleh Peunoh Daly, yang mengemukakan bahwa definisi hadhanah ialah pekerjaan yang berhubungan dengan memelihara, merawat dan mendidik anak-anak yang masih kecil, tidak tau apa-apa dan lemah fisik. ${ }^{18}$

Hadhanah adalah suatu kewenangan untuk merawat dan mendidik orang yang belum mumayyiz atau orang yang dewasa tetapi kehilangan akal (kecerdasan berpikir) nya. Munculnya persoalan hadhanah tersebut adakalanya disebabkan oleh perceraian atau karena meninggal dunia dimana anak belum dewasa dan tidak mampu lagi mengurus diri mereka, karenanya diperlukan adanya orang-orang yang bertanggung jawab untuk merawat dan mendidik anak tersebut. ${ }^{19}$ Disebutkan juga sebagai berikut:

"Menurut istilah ahli fikih, hadhanah berarti memelihara anak dari segala macam bahaya yang mungkin menimpanya, menjaga kesehatan jasmani dan rohaninya, menjaga makanan dan keberaniannya, mengusahakan

${ }^{16}$ Sayyid Syabiq, Fiqh as-Sunnah, (Beirut: Darul Fikr, 1983), jilid 8, hal.

17 Neng Djubaedah, dkk. Hukum Perkawinan di Indonesia, (Jakarta: Sinar Grafindo, 2006), hal. 237

18 Peunoh Daly, Hukum Perkawinan Islam, (Jakarta: Bulan Bintang, 1988), hal. 399-400

${ }^{19}$ Andi Syamsu Alam dan M Fauzan, Hukum Pengangkatan Anak Perspektif Islam 
pendidikannya hingga ia sanggup berdiri sendiri dalam menghadapi kehidupannya sebagai seorang muslim". ${ }^{20}$ Dari pengertian-pengertian hadhanah di atas dapat disimpulkan bahwa hadhanah itu mencakup aspek-aspek yang meliputi pendidikan, pencukupan kebutuhan dan usia (yaitu bahwa hadhanah itu diberikan kepada anak sampai usia tertentu).

Dalam Islam, hadhanah itu sendiri wajib bagi orang tua. Sebagaimana wajib memeliharanya selama berada dalam ikatan perkawinan. Oleh karena itu, anak yang diasuh akan terancam masa depannya apabila tidak mendapatkan pengasuhan dan pemeliharaan dari kedua orang tua yang bercerai. Adapun yang menjadi dasar hukum disyariatkannya hadhanah antara lain firman Allah Swt dalam surat at-Tahrim ayat 6 yang berbunyi sebagai berikut.

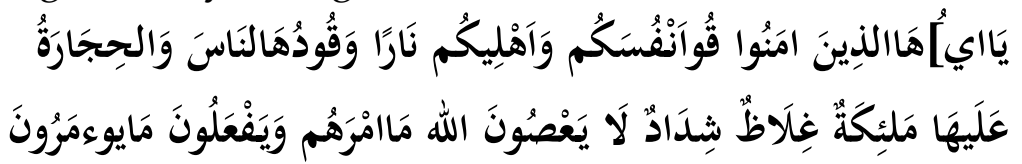

Terjemahannya:

"Hai orang-orang yang beriman, peliharalah dirimu dan keluarga mu dari api neraka yang bakarnya adalah manusia dan batu. Penjaganya malaikat-malaikat yang kasar, keras dan tidak mendurhakai Allah terhadap apa yang diperintahkanNya kepada mereka, dan selalu mengerjakan apa yang diperintahkan." (at-Tahrim: 6).

Pada ayat diatas dijelaskan bahwa orang tua diperintahkan Allah SWT untuk memelihara keluarganya dari api neraka, dengan upaya atau berusaha agar semua anggota kelurganya itu menjalankan semua perintahperintah dan larangan-larangan Allah SWT, termasuk anak. Berkaitan

${ }^{20}$ Kamal Muhtar, Asas-asas Hukum Islam Tentang Perkawinan (Jakarta: Bulan Bintang), hal.129

Sangaji Jurnal Pemikiran Syariah dan Hukum 
dengan hadhanah pasca perceraian pada masa Rasul Muhammad Saw masih hidup, berdasarkan penuturan dari Umar bin Syuaib yang meriwayatkan dari ayahnya, bahwa seorang perempuan datang kepada Rasulullah seraya berkata: "Ya Rasulullah, anak ini telah ku kandung dalam rahimku, telah $\mathrm{ku}$ susui dari air susu $\mathrm{ku}$, telah bernafas di kamarku, ayahnya (suamiku) menceraikanku dan menghendaki anak ini dariku." Rasulullah kemudian bersabda:

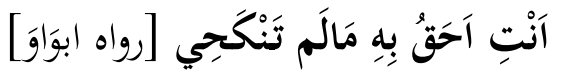

Terjemahannya:

"Kamu lebih berhak memeliharanya daripada dia (suami mu) sebelum kamu menikah lagi." (HR. Abu Daud)

Hadis ini menjelaskan bahwa Ibu lebih berhak daripada Bapak sebelum Ibunya menikah lagi. Ibu lebih diutamakan karena mempunyai kelayakan mengasuh dan menyusui, mengingat ibu lebih mengerti dan mampu mendidik anak. Kesabaran ibu dalam hal ini lebih besar daripada bapak. Waktu yang dimiliki ibu lebih lapang daripada Bapak. Karena itu, ibu lebih diutamakan untuk menjaga kemaslahatan anak.

Dalam konsep Islam tanggung jawab ekonomi berada di pundak suami sebagai kepala rumah tangga, meskipun dalam hal ini tidak menutup kemungkinan istri membantu suami dalam menanggung kewajiban ekonomi tersebut. Karena itu yang terpenting adalah adanya kerjasama dan tolong menolong antara suami istri dalam memelihara anak dan menghantarkannya hingga anak tersebut dewasa. ${ }^{21}$ Para ulama menetapkan bahwa pemeliharaan anak itu hukumnya adalah wajib, sebagaimana wajib memeliharanya dalam ikatan

${ }^{21}$ Ahmad Rofiq, Hukum Islam di Indonesia, (Jakarta: Raja Grafindo), 
perkawinan. Adapun dasar hukum mengikuti perintah Allah untuk membiayai anak dan istri ${ }^{22}$ dalam firman Allah surat alBaqarah: 233 sebagai berikut.

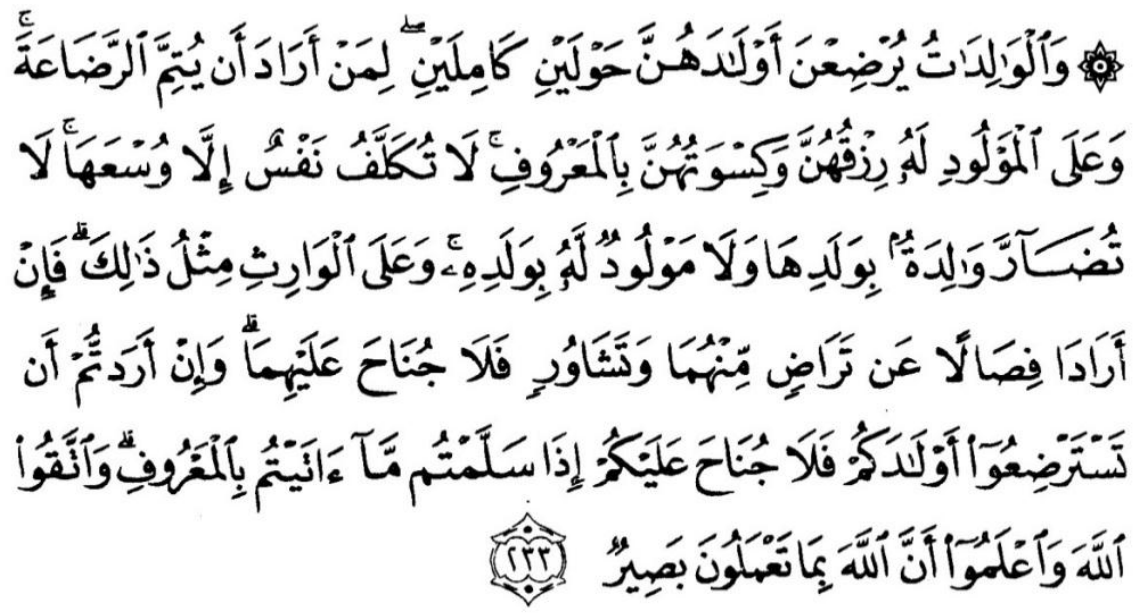

Terjemahannya:

"Para ibu hendaklah menyusukan anak-anaknya selama dua tahun penuh, yaitu bagi yang ingin menyempurnakan penyusuan. Dan kewajiban ayah memberi makan dan pakaian kepada para ibu dengan cara ma'ruf. Seseorang tidak dibebani melainkan menurut kadar kesanggupannya. Janganlah seorang ibu menderita kesengsaraan karena anaknya dan seorang ayah karena anaknya, dan warispun berkewajiban demikian. Apabila keduanya ingin menyapih (sebelum dua tahun) dengan kerelaan keduanya dan permusyawaratan, maka tidak ada dosa atas keduanya. Dan jika kamu ingin anakmu disusukan oleh orang lain, maka tidak ada dosa bagimu apabila kamu memberikan pembayaran menurut yang patut. Bertakwalah kamu kepada Allah dan ketahuilah bahwa Allah Maha Melihat apa yang kamu kerjakan." (al-Baqarah: 233)

${ }^{22}$ Amir Syarifuddin, Hukum Perkawinan Islam...., hal. 328.

Sangaji Jurnal Pemikiran Syariah dan Hukum 
Bila terjadi pemutusan perkawinan karena perceraian, baik ibu maupun bapak tetap berkewajiban memelihara dan mendidik anak-anaknya semata-mata demi kepentingan si anak. ${ }^{23}$ apabila perceraian terjadi antara suami istri yang telah berketurunan, yang berhak mengasuh anak pada dasarnya adalah istri, ibu anak-anak. ${ }^{24}$ Ibu lebih berhak merawat anak dasarnya Al-Baqarah 233, dan Kandungan Hadits Riwayat Abu Daud di atas:

1. Ibu lebih berhak mengasuh anaknya selama anak berada dalam tahap kebutuhan asuhan dan selama ibu belum kawin lagi. Jika ibu kawin lagi, maka tidak ada hak untuk mengasuh anak lagi.

2. Ibu yang kawin lagi masih berhak mengasuh anaknya tanpa perselisihan ulama. ${ }^{25}$

Dalam kandungan hadits yang disahihkan oleh Tirmidzi (Bulughul Maram 1189) memiliki kandungan:

1. Anak yang sudah tidak memerlukan pemeliharaan dan asuhan berhak memilih, ikut ibunya atau ayahnya.

2. Jika anak tidak menentukan pilihan, Ibnul Qayyim berpendapat, bahwa yang diserahi anak adalah orang tua yang paling maslahat bagi anak.

3. Menurut segolongan ulama batas umur anak tersebut ialah 7 tahun. $^{26}$

23 Amiur Nuruddin dan Azhari Akmal Tarigan, Hukum Perdata Islam...., hal. 295.

24 Ahmad Azhar Basyir, Hukum Perkawinan Islam disertai Perbandingan dengan Undang-Undang Perkawinan No.1 Tahun 1974, (Yogyakarta: Gadjah Mada University Press,1989), hal. 91

${ }^{25}$ Ibid., hal. 189

${ }^{26}$ Ibid., hal. 190 


\section{Hak Anak (hadhanah) Pasca Perceraian Perspektif Hukum Positif Indonesia}

\section{a. Undang-undang Nomor 1 Tahun 1974}

Pertanggungjawaban ayah terhadap biaya pemeliharaan anak tidak dapat dilepaskan dari kebijakan legislatif yang tertuang dalam Undang-undang Perkawinan maupun Kompilasi Hukum Islam. Kedua peraturan tersebut telah mencantumkan beberapa ketentuan tentang kewajiban orang tua (khususnya ayah) terhadap anak-anaknya. Pasal 45 Undang-undang Nomor 1 tahun 1974 menyebutkan bahwa orang tua wajib memelihara dan mendidik anak sebaik-baiknya sampai anak itu kawin atau berdiri sendiri, dan kewajiban ini akan terus berlaku meskipun perkawinan kedua orang tuanya putus. Selanjutnya pasal 46 Undang-undang ini menambahkan bahwa anak wajib menghormati orang tuanya dan mentaati kehendak mereka dengan baik, dan apabila telah dewasa anak wajib memelihara orang tua dan keluarganya menurut kemampuannya apabila mereka membutuhkan bantuan.

Akibat putusnya perkawinan karena perceraian, pasal 41 Undang-undang nomor 1 tahun 1974 menyebutkan bahwa:

1) Baik ibu atau bapak berkewajiban memelihara dan mendidik anak-anaknya, semata-mata berdasarkan kepentingan anak, bilamana ada perselisihan mengenai penguasaan anak, pengadilan memberikan keputusan;

2) Bapak yang bertanggungjawab atas semua biaya pemeliharaan dan pendidikan yang diperlukan anak, dan bila ternyata dalam kenyataannya bapak tidak dapat memenuhi kewajiban tersebut, maka pengadilan dapat menentukan bahwa ibu ikut memikul kewajiban tersebut;

Sangaji Jurnal Pemikiran Syariah dan Hukum 
3) Pengadilan dapat mewajibkan kepada bekas suami untuk memberikan biaya penghidupan dan/atau menentukan suatu kewajiban bagi bekas istri.

Apabila terjadi kealpaan atau kelalaian oleh orang tuanya dengan sengaja atau tidak melakukan tanggung jawabnya sebagai orang tua maka dapatlah dituntut dengan mengajukan gugatan ke pengadilan. ${ }^{27}$ Bagi salah satu orang tua yang melalaikan kewajibannya tersebut menurut pasal 49 UU nomor 1 Tahun 1974 tentang Perkawinan dapat dicabut kekuasaannya atas permintaan orang tua yang lain.

\section{b. Perspektif Undang-Undang Nomor 23 Tahun 2002}

Perlindungan anak dapat dilakukan secara langsung maupun tidak langsung. Secara langsung maksudnya kegiatannya langsung ditujukan kepada anak yang menjadi sasaran pelanggaran langsung. Kegiatan seperti ini dapat dengan cara melindungi anak dari berbagai ancaman dari luar dan dalam seperti mendidik, membina, mendampingi anak dengan berbagai cara. Perlindungan anak secara tidak langsung yaitu kegiatan tidak langsung ditujukan kepada anak, tetapi orang lain yang melakukan atau terlibat dalam usaha perlindungan anak. ${ }^{28}$ Dalam UU.No. 23 Tahun 2002 tentang perlindungan anak disebutkan:

Pasal 1 (2) "Perlindungan anak adalah segala kegiatan untuk menjamin dan melindungi anak dan hakhaknya agar dapat hidup, tumbuh, berkembang,

${ }^{27}$ Hilman Hadikusuma, Hukum Perkawinan Indonesia (Bandung: CV Mandar Maju, 1990), hal.144

${ }^{28}$ Ibid., hal. 38 
dan berpartisipasi, secara optimal sesuai dengan harkat dan martabat kemanusiaan, serta mendapat perlindungan dari kekerasan dan diskriminasi."

Pasal 8 "Setiap anak berhak memperoleh pelayanan kesehatan dan jaminan social sesuai dengan kebutuhan fisik, mental, spiritual, dan sosial."

Pasal 13 (1) "Setiap anak selama dalam pengasuhan orang tua, wali, atau pihak lain mana pun yang bertanggung jawab atas pengasuhan, berhak mendapat perlindungan dari perlakuan: a. Diskriminasi; b. Eksploitasi, baik ekonomi maupu seksual; c. Penelantaran; Kekejaman, kekerasan, dan penganiayaan; e. Ketidakadilan; dan f. Perlakuan salah lainnya."

(2) "Dalam hal orang tua, wali atau pengasuh anak melakukan segala bentuk perlakuan sebagaimana dimaksud dalam ayat 1, maka pelaku dikenakan pemberatan hukuman."

Pasal 16 1. Setiap anak berhak memperoleh perlindungan dari sasaran penganiayaan, penyiksaan, atau penjatuhan hukuman yang tidak manusiawi. 2 . Setiap anak berhak untuk memperolah kebebasan sesuai dengan hukum. 3. Penangkapan, penahanan, atau tindal pidana penjara anak hanya dilakukan apabila sesuai dengan hukum yang berlaku dan hanya dapat dilakukan sebagai upaya terakhir.

Pasal 26 a. Mengasuh, memelihara, mendidik, dan melindungi anak $b$. Menumbuh kembangkan anak sesuai dengan kemampuan, bakat dan minatnya. c. Mencegah terjadinya perkawinan pada usia anakanak 
Pasal 36 1) Dalam hal wali yang ditunjuk ternyata kemudian hari tidak cakap melakukan perbuatan hukum atau menyalahgunakan kekuasaannya sebagai wali, maka status perwaliannya dicabut dan ditunjuk orang lain sebagai wali melalui penetapan pengadilan. 2) Dalam hal wali meninggal dunia, ditunjuk orang lain sebagai wali melalui penetapan pengadilan.

Berdasarkan UU. No. 23 Tahun 2002 tentang Perlindungan Anak juga disebutkan hak dan kewajiban anak, dalam Undang-undang ini perlindungan anak sangat lebih diutamakan, dimana hal ini tetap harus dilakukan meskipun diantara ibu atau ayahnya yang bersengketa salah satunya berkeyakinan di luar Islam, atau diantara mereka berlainan bangsa, namun dalam memutuskan terhadap pilihan anak tersebut harus melihat untuk kemaslahatan anak tersebut yang dalam hal ini bukan hanya kemaslahatan dunianya saja tetapi juga adalah akhir dari dunia ini yaitu akhiratnya.

Pasal 14 UU No. 23 Tahun 2002 tentang Perlindungan Anak, yang menyatakan: "Setiap anak berhak untuk diasuh oleh orang tuanya sendiri, kecuali jika ada alasan dan/atau aturan hukum yang sah menunjukkan bahwa pemisahan itu adalah demi kepentingan terbaik bagi anak dan merupakan pertimbangan terakhir".

Dalam penjelesannya ditegaskan bahwa, "Pemisahan yang dimaksud dalam ketentuan ini tidak menghilangkan hubungan anak dengan orang tuanya". Jadi, meskipun sudah ada ketentuan hukumnya yang menyatakan salah satu orang tua sebagai pemegang "kuasa 
asuh anak", tetap tidak ada alasan untuk melarang orang tua lain bertemu dengan anaknya. ${ }^{29}$

\section{c. Hukum Perdata}

Pemeliharaan anak terdapat dalam Kitab UndangUndang Hukum Perdata Buku ke Satu Hal Orang pada Bab X, XI dan XIV. Pada pasal 289 bab XIV tentang Kekuasaan Orang Tua bagian 1 Akibat-Akibat Kekuasaan Orang Tua Terhadap Pribadi Anak dalam Kitab Undang-Undang Hukum Perdata menyatakan bahwa setiap anak berapapun umurnya wajib menghormati dan menghargai kedua orang tuanya. Dalam tinjauan Hukum Perdata mengenai siapa yang paling berhak memelihara atau mengasuh anak yang masih dibawah umur, akibat dari perceraian suami isteri adalah kewajiban kedua orang tuanya. Kehilangan kekuasaan orang tua atau kekuasaan wali tidak membebaskan mereka dari kewajiban untuk memberi tunjangan menurut besaran pendapatan mereka guna membiayai pemeliharaan dan pendidikan anaknya. ${ }^{30}$

Kemudian dijelaskan pada pasal 299 Bab XIV tentang Kekuasaan Orang Tua bagian 1 Akibat-Akibat Kekuasaan Orang Tua Terhadap Pribadi Anak dalam Kitab Undang-Undang Hukum Perdata bahwa selama perkawinan orang tuanya, setiap anak sampai dewasa tetap berada dalam kekuasaan kedua orang tuanya, sejauh orang tua tersebut tidak dilepaskan dari kekuasaan itu. Kecuali jika terjadi pelepasan atau pemecatan dan berlaku ketentuan-ketentuan megenai pisah meja dan pisah

${ }^{29}$ Adib Bahari, Prosedur Gugatan Cerai, Pembagian Harta Gono-Gini dan Hak Asuh Anak, (Yogyakarta: Pustaka Yustisia, 2012), hal. 166

30 Soedharyo Soimin, Kitab Undang-Undang Hukum Perdata, (Jakarta: Sinar Grafika, 2007), hal. 72

Sangaji Jurnal Pemikiran Syariah dan Hukum 
ranjang, Bapak sendiri yang melakukan kekuasaan itu. Bila Bapak berada dalam keadaan tidak mungkin untuk melakukan kekuasaan orang tua, kecuali dalam hal adanya pisah meja dan ranjang. Bila Ibu juga tidak dapat atau tidak berwenang, maka oleh Pengadilan Negeri diangkat seorang Wali sesuai dengan pasal 359. Hal ini terdapat dalam pasal 300 bab XIV tentang Kekuasaan Orang Tua bagian 1 Akibat-Akibat Kekuasaan Orang Tua Terhadap Pribadi Anak dalam Kitab Undang-Undang Hukum Perdata. ${ }^{31}$

Mengenai pemeliharaan anak yang masih di bawah umur, diatur dalam pasal 229 bab X tentang Pembubaran Perkawinan pada umumnya dalam Kitab Undang-Undang Hukum Perdata yang berisi: "Setelah memutuskan perceraian, dan mendengar atau memanggil dengan sah para orang tua atau keluarga sedarah atau semenda dari anak-anak yang dibawah umur, Pengadilan Negeri akan menetapkan siapa dari kedua orang tua akan melakukan perwalian atas tiap-tiap anak, kecuali jika kedua orang tua itu dipecat atau dilepaskan dari kekuasaan orang tua, dengan mengindahkan putusan-putusan hakim terdahulu yang mungkin memecat atau melepas mereka dari kekuasaan sebagai orang tua." 32

Dari uraian tersebut di atas, bahwa setelah adanya kekuasaan orang tuaatau para wali atau yang ditetapkan oleh Pengadilan, kecuali keduanya telah dipecat dari kekuasaannya, dikarenakan telah melalaikan tugas atau berperilaku tidak baik. Jadi menurut Hukum Perdata, bahwa hak memelihara atau mengasuh anak yang masih kecil tetap berada dalam tanggungan orang tua baik Ayah maupun Ibunya.

${ }^{31}$ Ibid., hal. 76
${ }^{32}$ Ibid., hal. 72 
Sebagaimana dijelaskan pula dalam 231 bab X tentang Pembubaran Perkawinan pada umumnya dalam Kitab Undang-Undang Hukum Perdata: "Bubarnya perkawinan karena perceraian tidak menyebabkan anakanak yang lahir dari perkawinan itu kehilangan keuntungan yang telah dijamin bagi mereka oleh Undangundang atau oleh perjanjian perkawinan orang tua mereka."

Menurut pasal tersebut di atas bahwa hak mengasuh anak kecil meskipun orang tuanya telah bercerai, tetap berada dalam tanggungan orang tuanya, dengan syarat anak tersebut adalah anak yang lahir dari perkawinan yang sah.

\section{d. Kompilasi Hukum Islam}

Tidak berbeda dengan Undang-undang Nomor 1 Tahun 1974, pasal 104 (1) Kompilasi Hukum Islam disebutkan dengan jelas bahwa: "semua biaya penyusuan anak dipertanggungjawabkan kepada ayahnya, apabila ayahnya telah meninggal dunia, maka biaya penyusuan dibebankan kepada orang yang berkewajiban memberi nafkah kepada ayahnya atau walinya".

Lebih lanjut dijelaskan dalam pasal 105 Kompilasi Hukum Islam, dalam hal terjadinya perceraian bahwa:

"Pemeliharaan anak yang belum mumayyiz atau belum berumur 12 tahun adalah hak ibunya, sedangkan yang sudah mumayyiz diserahkan kepada anak untuk memilih antara ayah atau ibunya sebagai pemegang hak pemeliharaannya dengan biaya pemeliharaan ditanggung oleh ayahnya".

Mengenai pemeliharaan anak, Kompilasi Hukum Islam memberikan pengaturan sebagaimana yang terdapat dalam bab XIV Pasal 98 yaitu:'

Sangaji Jurnal Pemikiran Syariah dan Hukum 
a. Batas usia anak yang mampu berdiri sendiri atau dewasa adalah 21 tahun, sepanjang anak tersebut tidak cacat fisik maupun mental atau belum pernah melangsungkan perkawinan;

b. Orang tuanya mewakili anak tersebut mengenai segala perbuatan hukum di dalam dan di luar pengadilan;

c. Pengadilan Agama dapat menunjuk salah seorang kerabat terdekat yang mampu menunaikan kewajiban tersebut apabila kedua orang tuanya tidak mampu.

Lebih lanjut pasal 156 Kompilasi Hukum Islam mengatur tentang pemeliharaan anak ketika ibu kandungnya meninggal dunia dengan memberikan urutan yang berhak memelihara anak, antara lain:

a. Anak yang belum mumayyiz berhak mendapatkan hadhanah dari ibunya, kecuali bila ibunya telah meninggal dunia, maka kedudukannya digantikan oleh:

(1) Wanita-wanita dalam garis lurus ke atas dari ibu;

(2) Ayah;

(3) Wanita-wanita dalam garis lurus ke atas dari ayah;

(4) Saudara perempuan dari anak yang bersangkutan;

(5) Wanita-wanita kerabat sedarah menurut garis samping dari ayah.

b. Anak yang sudah mumayyiz berhak memilih untuk mendapatkan hadhanah dari ayah atau ibunya;

c. Apabila pemegang hadhanah ternyata tidak dapat menjamin keselamatan jasmani dan rohani anak, meskipun biaya nafkah dan hadhanah telah dicukupi, maka atas permintaan kerabat yang 
bersangkutan Pengadilan Agama dapat memindahkan hak hadhanah kepada kerabat lain yang mempunyai hak hadhanah pula;

d. Semua biaya hadhanah dan nafkah anak menjadi tanggung jawab ayah menurut kemampuannya, sekurang-kurangnya sampai anak tersebut dewasa dapat mengurus diri sendiri (21 tahun);

e. Bilamana terjadi perselisihan mengenai hadhanah dan nafkah anak, Pengadilan Agama memberikan putusannya berdasarkan huruf (a), (b), dan (c);

f. Pengadilan dapat pula dengan mengingat kemampuan ayahnya menetapkan jumlah biaya untuk pemeliharaan dan pendidikan anak-anak yang tidak turut padanya.

Kekuasaan orang tua terhadap anak pasca perceraian menurut ketentuan kedua UU adalah sejalan, dan harus dianggap logis mengingat makna kekuasaan orang tua terhadap anak sangat berkolerasi terhadap makna perkawinan dan perceraian sebagaimana diatur oleh KHI dan UU Perkawinan. Pemaknaan yang terdapat di dalam kedua UU ini ternyata juga sejalan dengan pemaknaan perlindungan anak sebagaimana diatur di dalam UU Perlindungan anak, yaitu memberikan yang terbaik kepada anak. Dengan demikian pemaknaan kekuasaan orang tua terhadap anak pasca perceraian, di dalam konteks hubungan antara KHI dan UU Perlindungan Anak, adalah memiliki tingkat harmonisasi yang baik. Adapun orang yang berhak melakukan pemeliharaan anak Dalam pasal 41 (a) UU Perkawinan adalah Baik ibu atau bapak tetap berkewajiban memelihara dan mendidik anak-anaknya, semata-mata berdasarkan kepentingan anak, bilamana ada perselisihan mengenai penguasaan anak-anak, Pengadilan memberi keputusan.

Sangaji Jurnal Pemikiran Syariah dan Hukum 
Pada prinsipnya, baik ibu maupun bapak diberikan hak yang sama untuk melakukan pemeliharaan dan pendidikan terhadap anak-anaknya setelah terjadi perceraian. Oleh karena itu keduanya dapat mufakat siapa akan anak tersebut. Akan tetapi apabila terjadi perselisihan, maka persoalan diserahkan kepada Pengadilan. Pengadilanlah yang harus memilih dan menetapkan siapa di antara kedua orang tua yang sama-sama berhak akan melaksanakan pemeliharaan, untuk itu Pengadilan harus memeriksa dengan teliti siapakah di antara mereka yang lebih baik mengurus kepentingan anak. ${ }^{33}$ Sedangkan tentang biaya pemeliharaan anak, biaya pemeliharaan dan pendidikan anak diatur dalam pasal 41 (b) dan 49 ayat 2 UU Perkawinan. Dalam pasal 41 (b) UU Perkawinan:

“Bapak yang bertanggung jawab atas semua biaya pemeliharaan dan pendidikan yang diperlukan anak itu, bilamana bapak dalam kenyataannya tidak dapat memberi kewajiban tersebut Pengadilan dapat menentukan bahwa ibu ikut memikul biaya tersebut."

Dari bunyi ketentuan tersebut dapat kita simpulkan, baik anak itu di bawah pemeliharaan bapak atau ibu, maka yang menjamin jumlah biaya pemeliharaan dan pendidikan anak ialah bapak. Mengenai jumlah besarnya biaya ditentukan atas dasar kebutuhan anak, dan ketentuan tersebut diselaraskan dengan keadaan ekonomi orang tua. Apabila orang tua dalam keadaan kuat ekonominya, maka ia wajib memberikan biaya sesuai dengan kebutuhan anak. Sebaliknya apabila keadaan ekonomi orang tua dalam kesulitan maka ibu juga wajib membiayai anak. Dalam pasal 49 ayat 2 UU Perkawinan, meskipun orang tua dicabut

${ }_{33}$ M. Yahya Harahap, Hukum Perkawinan Nasional, (Medan: Zahir Trading, 2001), hal. 159 
kekuasaannya, mereka masih berkewajiban untuk memberi pemeliharaan kepada anak tersebut.

Dari bunyi ketentuan tersebut dapat kita simpulkan, baik anak itu di bawah pemeliharaan bapak atau ibu, maka yang menjamin jumlah biaya pemeliharaan dan pendidikan anak ialah bapak. Mengenai jumlah besarnya biaya ditentukan atas dasar kebutuhan anak, dan ketentuan tersebut diselaraskan dengan keadaan ekonomi orang tua. Apabila orang tua dalam keadaan kuat ekonominya, maka wajib memberikan biaya sesuai dengan kebutuhan anak. Sebaliknya apabila keadaan ekonomi orang tua dalam keadaan lemah, maka kewajiban orang tua itu harus sesuai dengan kebutuhannya. Mengenai batas kewajiban pemeliharaan anak. Batas kewajiban Pemeliharaan dan pendidikan anak diatur pula, dalam pasal 45 ayat 2 UU Perkawinan: Kewajiban orang tua yang dimaksud dalam ayat (1) pasal ini berlaku sampai anak itu kawin atau dapat berdiri sendiri kewajiban mana berlaku terus meskipun perkawinan antara kedua orang tua putus.

Jadi pokok-pokok batas kewajiban orang tua untuk memelihara dan mendidik anak-anaknya tidak ditentukan sampai batas umur tertentu, tetapi dilihat dari keadaan anak itu, Apabila anak dianggap telah dapat berdiri sendiri atau telah kawin, maka terlepaslah kewajiban orang tua untuk memelihara dan mendidiknya walaupun anak baru berumur 17 tahun, sebaliknya anak yang telah berumur 25 tahun tetapi belum mampu berdiri sendiri maka orang tua masih berkewajiban memelihara dan mendidik. 


\section{Perbandingan Hak Anak (Hadhanah) Pasca Perceraian Perspektif Hukum Positif Indonesia dan Perspektif Hukum Islam}

Secara umum, hak anak terkait pemeliharaan dan pengasuhan atau hadhanah dalam hukum positif maupun hukum Islam tidak jauh berbeda. Hanya saja dalam beberapa hal tentang pemeliharaan anak dalam hukum positif belum memberikan uraian secara rinci dan tegas, hanya menjelaskan "demi kepentingan terbaik anak." Dalam Kitab UndangUndang Hukum Perdata, meskipun hak dan kewajiban sebagai suami isteri telah berakhir (akibat perceraian), namun kwajiban sebagai orang tua masih terus berlanjut. Kekuasaan orang tua dihapus dan diganti menjadi perwalian. Menurut pasal 229 Kitab Undang-Undang Hukum Perdata, Pengadilan menentukan wali anak dibawah umur. Apabila pihak yang diserahkan sebagai wali kurang mampu membiayai pemeliharaan dan pendidikan anak, maka menurut pasal 230b Kitab Undang-Undang Hukum Perdata, Hakim dapat menentukan sejumlah uang yang harus dibayar pihak yang lain untuk membiayai anak dibawah umur. Selanjutnya berdasarkan ketentuan pasal 41 (a) Undang-Undang Nomor 1 tahun 1974 tentang Perkawinan yang berbunyi: “Baik ibu atau bapak tetap berkewajiban memelihara dan mendidik anakanaknya, semata-mata berdasarkan kepentingan anak."

Menurut Undang-Undang Nomor 1 tahun 1974 tentang Perkawinan pasal 41 antara lain:

1. Baik bapak atau ibu tetp berkewajiban memelihara dan mendidik anak-anaknya, semata-mata berdasarkan kepentingan anak. Bilamana ada perselisihan mengenai penguasaan anak, pengadilan akan memberikan keputusan.

2. Biaya pemeliharaan dan pendidikan anak-anak menjadi tanggung jawab pihak bapak, kecuali dalam pelaksanaan pihak bapak tidak dapat melakukan tersebut, maka 
Pengadilan dapat menentukan bahwa ibu ikut memikul biaya tersebut.

Pengadilan dapat pula memberikan keputusan tentang siapa diantara mereka berdua yang mengusai anak (memelihara dan mendidiknya) apabila terjadi perselisihan diantara keduanya. Keputusan pengadilan dalam hal ini tentu didasarkan pada kepentingan anak. Dalam Undang-Undang nomor 23 tahun 2002 pasal 2, meletakkan kewajiban memberikan perlindungan kepada anak berdasarkan asas kepentingan yang terbaik bagi anak. Selanjutnya masih dalam Undang-Undang nomor 23 tahun 2002 tentang Perlidungan Anak pasal 26 ayat 1 disebutkan bahwa orang tua berkewajiban dan bertanggung jawab untuk mengasuh, memelihara, mendidik dan meindungi anak, menumbuhkembangkan anak sesuai dengan kemampuan, bakat dan minatnya serta mencegah terjadinya perkawinan pada usia anak-anak. ${ }^{34}$

Dalam sudut pandang yang dibangun oleh hukum Islam, anak merupakan makhluk yang dhaif dan mulia, yang keberadaannya adalah atas kewenangan dan kehendak Allah SWT dengan melalui beberapa proses penciptaanya yang dimensinya sesuai dengan kehendak Allah Swt. Kedudukan anak dalam Agama Islam ditegaskan dalam Al-qur'an Surah alIsra' ayat (70).

Artinya: "Dan sesungguhnya telah Kami muliakan Anakanak Adam. Kami angkut mereka di daratan dan di lautan. Kami beri rezki dari yang baik-baik dan Kami lebihkan mereka dengan kelebihan yang sempurna atas kebanyakan makhluk yang telah Kami ciptakan."

34 Riska Saraswati, Hukum Pelindungan Anak di Indonesia, (Bandung: Citra Aditya Bakti, 2009), hal.24-25

Sangaji Jurnal Pemikiran Syariah dan Hukum 
Penjelasan Surah al-Isra ayat 70 tersebut diikuti dengan Hadist Nabi Muhammad Saw yang artinya "Semua anak dilahirkan atas kesucian, sehingga ia jelas bicaranya". ${ }^{35}$ Secara rasional, seorang anak terbentuk dari unsur gaib yang transedental dari proses ratifikasi sains (ilmu pengetahuan) dengan unsur-unsur Ilahiah yang diambil dari nilai-nilai material alam semesta dan nilai-nilai spiritual yang diambil dari proses keyakinan (Tauhid Islam). ${ }^{36}$ Dalam pandangan ini Abdul Rozak Husein menyatakan sebagai berikut: "Jika benih anak masyarakat itu baik maka sudah pasti masyarakat akan terbentuk menjadi masyarakat yang baik pula, lebih lanjut dikatakan: Islam menyatakan bahwa anak-anak merupakan benih yang akan tumbuh untuk membentuk masyarakat dimasa yang akan datang". ${ }^{37}$

Di dalam Pasal 106 ayat (1) dan (2) Kompilasi Hukum Islam disebutkan tentang kewajiban orang tua terhadap anaknya antara lain.

1. Orang tua berkewajiban merawat dan mengembangkan harta anaknya yang belum atau dibawah pengampuan, dan tidak boleh memindahkan atau menggandakannya kecuali karena keperluan yang mendesak, jika kepentingan dan kemaslahatan anak itu menghendaki atau suatu kenyataan yang tidak dapat dihindarkan lagi.

2. Orang tua bertanggung jawab atas kerugian yang ditimbulkan karena kesalahan dan kelalaian dari kewajiban tersebut pada ayat (1).

35 T.M. Hasbi Ashshiddiqi, Pengantar Figh Mu'amalah, (Semarang: Pustaka Rizki Putra, 1997), hal. 12.

${ }^{36}$ Hasan Wadong, Pengantar Advokasi dan Hukum Perlindungan Anak, (Jakarta: Gramedia, 2000), hal. 6

37 Abdul Rozak Husein, Hak-hak Anak Dalam Islam, (Jakarta: Fikahayati Aneska, 2002), hal. 21 
Dengan demikian dapat disimpulkan, bahwa pada dasarnya anak merupakan titipan atau amanah Allah Swt yang harus dijaga dan dibina dengan sungguh-sungguh oleh kedua orangtuanya. Mendidik agar manusia berguna dari dunia akhirat, memberi pelajaran dan ilmu-ilmu yang bermanfaat. Orang tua berkewajiban memelihara dan mendidik supaya anak tersebut dapat berdiri sendiri.

Di dalam Pasal 104 KHI disebutkan sebagai berikut:

1. Semua biaya penyusuan anak dipertanggung jawabkan kepada ayahnya. Apabila ayahnya telah meninggal dunia, maka biaya penyusuan dibebankan kepada orang tua yang berkewajiban memberi nafkah kepada ayah atau walinya.

2. Penyusuan dilakukan untuk paling lama dua tahun, dan dapat dilakukan penyampihan dalam masa kurang dua tahun, dengan persetujuan ayah dan ibunya.

Selanjutnya dalam ketentuan Kompilasi Hukum Islam Pasal 105 ditegaskan, bahwa, dalam hal terjadi perceraian:

1. Pemeliharaan anak yang belum mumayyiz atau belum berumur 12 tahun adalah hak ibunya;

2. Pemeliharaan anak yang sudah mumayyiz serahkan kepada anak untuk memilih di antara ayah atau ibunya sebagai pemegang hak pemeliharaan;

3. Biaya pemeliharaan ditanggung oleh ayahnya;

Dengan memperhatikan ketiga Pasal yang tercantum dalam Kompilasi Hukum Islam nampak jelas, bahwa kepada orang tua dibebankan tanggung jawab terhadap anak-anaknya meskipun telah terjadinya perceraian antara kedua orang tuanya.Ketentuan dalam hukum positif ini sesuai dengan ketentuan fikih, yaitu sama-sama mengutamakan kemaslahatan anak. Dalam ketentuan fikih, ibu lebih berhak dan diutamakan melakukan hadhanah daripada bapak. Karena ibu mempunyai kelayakan mengasuh dan mendidik serta lebih diutamakan untuk menjaga kemaslahatan anak.

Sangaji Jurnal Pemikiran Syariah dan Hukum 
Dalam hukum Islam, diwajibkan memelihara anak sampai anak mampu mandiri tanpa mengharap bantuan orang lain. Oleh karena itu, mengasuh anak yang masih kecil adalah wajib, karena dengan mengabaikan anak sama saja dengan membiarkan mereka dalam keadaan bahaya. Seperti yang tertulis jelas dalam surat al-Baqarah: 233 yang memerintahkan ibu untuk menyusui anak-anaknya selama dua tahun penuh. Namun di sini juga diberikan pilihan kepada orang tua apabila hendak mengurangi masa pemberian ASI pada anak-anaknya, dengan tidak mengurangi kebutuhan anak secara substansial. Dari ayat tersebut, terkandung hukum yang mewajibkan orang tua -baik ayah maupun ibu yang masih dalam ikatan pernikah atau telah bercerai- untuk memberikan hak anak (baca: hadhanah) kepada anak-anaknya. Pengabaian terhadap hak anak (hadhanah) sama halnya dengan mendzalimi anak/penganiayaan terhadap anak itu sendiri.

Perceraian tidak akan menghilangkan atau menggugurkan kewajiban orang tua terhadap anaknya, bahwa kewajiban orang tua masih tetap sama, baik terjadi perceraian atau tidak terjadi perceraian. Anak tetap harus memperoleh hakhaknya sebagai seorang anak, hak untuk mendapatkan pengasuhan secara baik, hak untuk mendapat bimbingan serta kasih sayang dari orang tuanya, hak untuk mendapatkan pendidikan, hak untuk mendapatkan kebutuhan sandang, papan dan pangan secara wajar, serta hak-hak yang lain yang mendukung tumbuh kembang anak secara baik dan wajar.

Merujuk kepada KHI, akibat hukum bagi orang tua yang tidak melaksanakan kewajibannya kepada anak maka dapat diupayakan dua hal: Pertama, terhadap pihak yang dibebani biaya nafkah, apabila tidak melaksanakannya kewajibannya dapat dimintakan eksekusi. Kedua, terhadap pemegang kuasa asuh, apabila tidak melaksanakan kewajibannya maka dapat dimintakan permohonan pencabutan 
kuasa asuh. Akan tetapi pencabutan kuasa asuh tersebut tidak menjadikan kewajiban sebagai orang tua kepada anaknya gugur.

Memperhatikan penjelasan di atas, maka dapat dikatakan bahwa kepentingan pembinaan anak dari hadhinnya (pengasuhnya) memang tidak dapat dibatasi mengingat kebutuhan anak-anak harus dipenuhi. Untuk itu, bagi pengasuh anak (hadhin) harus pula terlebih dahulu dilengkapi keterampilan dari berbagai masalah yang menyangkut dengan hubungan psikologi anak yang selalu berkembang setiap saat. Hal ini penting, karena hadhin mempunyai peranan penting dalam membentuk sikap dan prilaku anak.

Orang tua sebagai hadhin wajib memberikan hadhanah dalam membimbing, membina dan mendidik anaknya berdasarkan petunjuk-petunjuk dari Allah dalam agamanya. Pada gilirannya ia dapat berhubungan dan beribadah kepada Allah dengan baik dan benar. Dengan demikian, anak harus mendapat asuhan, bimbingan dan pendidikan yang baik dan benar agar menjadi remaja, manusia dewasa dan orang tua yang beragama dan selalu hidup agamis. Sehingga dengan demikian, anak sebagai penerus generasi dan cita-cita orang tuanya, tumbuh dan berkembang menjadi manusia yang dapat memberikan harapan orang tua, masyarakat, bangsa dan negara dan sesuai dengan kehendak Allah. ${ }^{38}$

Dengan demikian, dipahami bahwa suatu lingkungan keluarga yang kondusif merupakan conditio sine quanon dalam implementasi hadhanah, khususnya dalam memberikan pendidikan yang benar dan maksimal terhadap anak. Namun demikian, hadhanah harus

38 Bakir Yusuf Barmawi, Pembinaan Kehidupan Beragama Islam Pada Anak dan Remaja, Semarang: Toha Putra (1993), 7

Sangaji Jurnal Pemikiran Syariah dan Hukum 
berorientasikan ke masa depan, dalam arti dpersiapkan untuk menghadapi perkembangan pembangunan di masa mendatang, yang mungkin jauh berbeda bentuk, nilai dan situasi kehidupan masyarakat dimasa kini.

\section{Simpulan}

Adapun beberapa hal yang dapat penulis simpulkan dari pembahasan tersebut di atas sebagai berikut.

1. Hadhanah dalam perspektif Hukum Islam merupakan perintah langsung dari Allah dan RasulNya yang tertuang dalam al-Qur'an dan Hadis. Perceraian orangtua dalam Islam tidak serta merta menghentikan kewajiban orangtua dalam melaksanakan tanggungjawabnya pada anak. Sehingga hadhanah dalam Hukum Islam adalah wajib. Adapun pelaksana hadhanah dalam fikih yang didahulukan adalah ibu, dan pihak keluarga ibu. Hal ini menjadi semacam consensus karena ibu memiliki kemampuan untuk mengasuh, memelihara dan mendidik anak. Sedangkan ayah dibebankan untuk menanggung biaya hadhanah secara ekonomi. Pelaksanaan hadhanah dalam Hukum Islam muncul beberaoa perbedaan pendapat, namun dalam pelaksanaannya para fuqaha tetap menganjurkan untuk mempertimbangkan kebutuhan dan kemaslahatan anak itu sendiri.

2. Hadhanah dalam Perspektif Hukum Positif Indonesia Pasca perceraian diatur dalam Kitab Undang-Undang Hukum Perdata, Undang-Undang nomor 1 tahun 1974, UndangUndang nomor 23 tahun 2002 dan Inpres nomor 1 tahun 1991 tentang pelaksanaan Kompilasi Hukum Islam. Hadhanah dalam Hukum Positif Indonesia disebutkan sebagai bentuk kewajiban orangtua terhadap anaknya, dan hal tersebut berlaku sejak adanya ikatan perkawinan hingga terputusnya kekuasaan orangtua (perceraian) terhadap anaknya. Perihal putusan perceraian, hadhanah dalam Hukum Positif Indonesia tetap 
mendapatkan perhatian penting, mengingat anak yang masih dibawah umur membutuhkan pengasuhan, perawatan dan pendidikan dari walinya. Adapun konflik dan perdebatan yang muncul pasca putusan perceraian tentang siapa yang layak melakukan hadhanah dapat diputuskan berdasarkan pertimbangan hakim di pengadilan.

3. Pasal-pasal KHI tentang hadhanah tersebut menegaskan bahwa kewajiban pengasuhan material dan non material merupakan dua hal yang tidak dapat dipisahkan. KHI tidak berbeda dengan UU Perkawinan, di mana secara umum tanggung jawab orang tua terhadap anak tetap melekat meskipun telah bercerai. Kekuasaan orang tua terhadap anak dijabarkan melalui perangkat ketentuan hak dan kewajiban anak, dan hak dan kewajiban orang tua terhadap kewajiban anak. Oleh karena itu perlakuan terhadap anak adalah berdasarkan prinsip pemberian yang terbaik bagi anak. Secara keseluruhan dapat dikatakan bahwa substansi dan semangat KHI tidak berbeda dengan UU Perkawinan.

\section{DAFTAR PUSTAKA}

Ali, Zainuddin. Hukum Perdata Islam di Indonesia, Jakarta: Sinar Grafika Indonesia, 2006.

Ashshiddiqi, T.M. Hasbi. Pengantar Fiqh Mu'amalah, Semarang: Pustaka Rizki Putra, 1997.

Bahari, Adib. Prosedur Gugatan Cerai, Pembagian Harta GonoGini dan Hak Asuh Anak, Yogyakarta: Pustaka Yustisia, 2012.

Barmawi, Bakir Yusuf. Pembinaan Kehidupan Beragama Islam Pada Anak dan Remaja, Semarang: Toha Putra 1993.

Basyir, Ahmad Azhar. Hukum Perkawinan Islam disertai Perbandingan dengan Undang-Undang Perkawinan No.1 Tahun 1974, Yogyakarta: Gadjah Mada University Press, 1989.

Sangaji Jurnal Pemikiran Syariah dan Hukum 
Dahlan, Abdul Aziz. Ensiklopedia Hukum Islam, Jakarta: Ichtiar Baru Van Hoepe, 1999.

Daly, Peunoh. Hukum Perkawinan Islam, Jakarta: Bulan Bintang, 1988.

Djubaedah, Neng dkk. Hukum Perkawinan di Indonesia, Jakarta: Sinar Grafindo, 2006.

Hadikusuma, Hilman. Hukum Perkawinan Indonesia, Bandung: CV Mandar Maju, 1990.

Harahap, M. Yahya. Hukum Perkawinan Nasional, Medan: Zahir Trading, 2001.

HS, Salim \& Nurbani, Erlies Septiana. Penerapan Teori Hukum Pada Penelitian Tesis dan Disertasi. Jakarta: Raja Grafindo Persada, 2013.

Husein, Abdul Rozak. Hak-hak Anak Dalam Islam, Jakarta: Fikahayati Aneska, 2002.

Manzhur, Ibnu. Lisan al-Araby, Mesir: Dar al-Maarif, tth.

Marzuki, Peter Mahmud. Penelitian Hukum, Jakarta: Kencana, 2009.

Muhtar, Kamal. Asas-asas Hukum Islam Tentang Perkawinan, Jakarta: Bulan Bintang.

Muhtar, Kamal. Asas-asas Hukum Islam tentang Perkawinan, Jakarta: Bulan Bintang.

Rofiq, Ahmad. Hukum Islam di Indonesia, Jakarta: Raja Grafindo. Saraswati, Riska. Hukum Pelindungan Anak di Indonesia, Bandung: Citra Aditya Bakti, 2009.

Soekanto, Soerjono dan Mamudji, Sri. Penelitian Hukum Normatif Suatu Tinjauan Singkat, Jakarta: Raja Grafindo Persada, 2009.

Soimin, Soedharyo. Kitab Undang-Undang Hukum Perdata, Jakarta: Sinar Grafika, 2007.

Suma, Muhammad Amin. Hukum Keluarga Islam di Dunia Islam, Jakarta: Raja Grafindo Persada, 2005.

Syabiq, Sayyid. Fiqh as-Sunnah, Beirut: Darul Fikr, 1983. 
Syarifuddin, Amir. Hukum Perkawinan di Indonesia, Jakarta: Kencana, 2006.

Yunus, Mahmud. Kamus Bahasa Arab-Indonesia, Jakarta: Hidakarya Agung, 2000.

Yusuf, Ahmad Muhammad. Ensiklopedi Tematis Ayat al-Qur'an dan Hadis Jilid 7, Jakarta: Widya Cahaya, 2009.

Qal'ahji, Muhammad Rawwas. Terj. M.Abdul Mujeb, Ensiklopedi Fiqh Umar Bin Khathab, Jakarta: Raja Grafindo Persada, 1999.

Wadong, Hasan. Pengantar Advokasi dan Hukum Perlindungan Anak, Jakarta:

Gramedia, 2000.

Zein, Satria Efendi M. Problematika Hukum Keluarga Islam Kontemporer (Analisis Yurisprudensi dengan Pendekatan Ushuliyya), (Jakarta: Prenada Media, 2004. 